\title{
The Resistance Threshold to the Amalgamation of Jurisdictions: MP's Attitudes About Budget Control and Social Identification in the Swiss Cantons
}

\author{
Nils Soguel and Manon Jaquerod
}

\section{INTRODUCTION}

Territorial and institutional reforms are continually being implemented around the world (Aulich 1999; Hanes et al. 2012; Jacobs 2004; Wollmann 2010; Kettunen or Vakkala et al. in this volume). They are the result of trade-offs between creating larger political entities which allow for more efficiency through economies of scale and reducing spillover effects, and smaller political entities that are more responsive to the individual citizen (Dearlove 1979). Many federalist countries promote jurisdictional amalgamations at the subnational level. In the case of voluntary amalgamations in Switzerland, the decision to do so in many cases requires a majority of local decision-makers to accept changes to jurisdictional boundaries. Such

\footnotetext{
N. Soguel $(\bowtie) \bullet$ M. Jaquerod

University of Lausanne, Lausanne, Switzerland

e-mail: nils.soguel@unil.ch; manon.jaquerod@unil.ch

(C) The Author(s) 2021

T. Bergström et al. (eds.), The Future of Local Self-Government, Palgrave Studies in Sub-National Governance, https://doi.org/10.1007/978-3-030-56059-1_10
} 
proposed mergers may meet vigorous opposition from locals who favour closeness to their government and jurisdictional borders that signal a specific identity. Amalgamating with another community can seem tantamount to a loss of identity and an end to a unique history.

The purpose of this article is to analyse the reluctance-or the readiness - to join another entity and social group in the context of rationally justified jurisdictional amalgamation. The analysis first considers the issues raised by existing cooperative ventures between jurisdictions, which aim to take advantage of economies of scale or reflect answers to growing organisational weaknesses. The downside is that cooperating can lead to a loss of control since part of the budget resources become earmarked to finance joint ventures. Amalgamation can be seen as a way to recover the lost control over the budget whilst making economies of scale and the internalisation of spillovers possible. Although locals may consider it a threat to their social identification.

More specifically, the aim is to locate the 'resistance threshold' to amalgamation and which factors influence the location of the threshold. This empirical investigation uses a survey conducted among the members of parliament in two Swiss cantons.

This chapter contributes to the literature on fiscal federalism, and to that of governmental amalgamation. To the best of our knowledge, the trade-off between the control over the budget and the social identification has not yet been investigated.

Section 2 briefly surveys the literature on cooperation between subnational jurisdictions and the theoretical implications of amalgamating them. Section 3 discusses Switzerland's institutions and why the country is a good exemplar. Section 4 summarises the organisation of the survey. Section 5 presents the resistance thresholds elicited from respondents, which are analysed in Section 6 to model the factors that influence them. Section 7 concludes the Chapter.

\section{Literature AND Hypothesis}

Functional territories, ones in which individuals and firms actually operate, are today often no longer congruent with the boundaries of existing jurisdictions (Keating 2013; Schraepen in this volume). This unbundling process (Ruggie 1993) has increasingly jeopardised the fiscal equivalence principle described by Olson (1969): the three circles of fiscal policythose who decide, those who benefit, and those who pay-coincide less 
and less, creating negative externalities (spillovers). Territorial fragmentation also hardly allows individual jurisdictions to exploit economies of scale and the provision of public services becomes inefficient (von Hagen 2002).

The literature offers various responses: financial transfers, outsourcing, horizontal intergovernmental cooperation, and amalgamation of jurisdictions (Blåka 2017). This chapter, however, contributes to this area of the literature from a different perspective. It questions how local decisionmakers trade off a horizontal cooperation that produces a 'democratic deficit' on the one hand for the jurisdictional amalgamation that involves a loss of identification on the other.

Horizontal cooperation between neighbouring jurisdictions provides a technical answer to the unbundling by creating intergovernmental joint ventures. ${ }^{1}$ It hopefully allows venturers, that is, individual governments, to gain access to economies of scale since the area of provision is extended for the public service concerned (e.g. education, transportation, housing, water protection). Thus, spillovers should be internalised, with the circle of the decision-makers coinciding with that of the users and the taxpayers.

However, Dafflon (2013), for example, argues that horizontal cooperation creates difficulties by inducing individual governments to lose part of their own control over the budget to the joint venture organisation. Each government is in the position of a purchaser with a limited possibility to express its views and to control the expenditure. The expenditure is divided between the venturers and each are expected to bow to finance its share. Local decision-makers lose part of the control they previously had. Thus, a 'democratic deficit' appears (Court of Auditors 2016). Of course, some civil servants or one or two members of the executive branch of each cooperating government participate in the governing body. However, such governing bodies hardly provide the kind of democratic legitimation a legislative body would provide.

The amalgamation of subnational public sector entities-in particular municipal mergers - also offers an answer to the unbundling, as shown in several studies in various countries, for example, Aulich (1999), Vetter and Kersting (2003) or Wollmann (2010). Most studies consider that it guarantees better democratic accountability than horizontal cooperation. Indeed, since it is larger than the pre-existing jurisdictions, an amalgamated jurisdiction offers a better fit to the functional territories that households actually inhabit. The scope of democratic decision-making better matches that of users and taxpayers (Dafflon 2013). 
Even though rationally justified, many proposals to merge jurisdictions are vigorously opposed (Hanes et al. 2012). The social identification theory developed by Tajfel and Turner (1979) explains this resistance. People categorise themselves in groups that provide a sense of social identity and a source of self-esteem. Belonging to a jurisdiction generates identification by providing the in-group with a common territory, a common name or culture compared to an out-group in another jurisdiction. The amalgamation of both groups - in and out - disrupts the differentiation process and undermines the self-esteem of members of the in-group. Amalgamation dampens local identification and is often perceived by citizens as a loss of satisfaction (Soguel and Silberstein 2015).

The phenomenon of differentiation implicitly underpins the 'strong nucleus' technique developed by Dafflon (2000). The foundation of the technique is that a jurisdiction usually cooperates horizontally with jurisdictions in which people share at least roughly the same views regarding public service provision as those of its own people. Populations mix through cooperation projects and get acquainted. The higher the number of jointly provided services between two jurisdictions, the less the differentiation and the less likely individuals are to oppose an amalgamation.

Based on this literature, we propose the following hypothesis:

The stronger the cooperation through joint ventures between jurisdictions, the more decision-makers lose control over public service provisions and the budget and, in turn, the higher the likelihood they would accept amalgamating with the other jurisdiction.

Our hypothesis stems from two changes triggered by horizontal cooperation. The first is that horizontal cooperation jeopardises the control over the budget and amalgamation enables decision-makers to recover the power to decide. The second is that horizontal cooperation gradually levels-out differences between populations of cooperating jurisdictions and paves the way towards amalgamation.

\section{Institutional Background in SWITZERLAND}

Switzerland's major subnational political institutions, the cantons, are responsible for providing many public services. They make extensive use of horizontal cooperation to provide them efficiently. From the time modern Switzerland was founded in 1848 to 2003, no less than 733 
intercantonal agreements (Konkordate) have been reached (Schöni 2005). These agreements currently face mounting criticism. According to Rühli and Rother (2017), cantonal parliaments do not look favourably on additional intercantonal joint ventures since it means a loss of power with respect to the executive branch of the cantonal government. According to Sciarini and Bochsler (2006), most existing agreements were contracted between only two cantons, with geographic proximity, language, and religion playing a role. No cantons have yet merged, though some scholars have argued for it (Rumley 2010), and several official reports have been published. Since 1969, only six efforts to merge cantons have been launched, some failing at a very late stage when rejected in a popular referendum. ${ }^{2}$ In the area of our survey (i.e. the cantons of Jura and Neuchâtel in northern Switzerland) merger efforts were also unsuccessful.

By comparison, many municipalities have amalgamated over the same period. Calciolari et al. (2013) have argued that the loss of control over the budget triggered by the proliferation of joint ventures between municipalities is an important driving force. Small municipalities are commonly involved in a dozen or so of such agreements in order to provide various public services. Municipal officials often refer to this phenomenon as the 'empty shell' syndrome.

Each joint venture is unique, with its own organisation, personnel, and budget, often owning its own infrastructure or even legally authorised to take out loans. Operating costs are split between the venturing jurisdictions, which raises the question what degree of control each jurisdiction still retains over the services provided and the level of expenditures.

\section{SurveY}

We mailed out a questionnaire we designed that was meant to elicit the 'resistance threshold' of respondents. ${ }^{3}$ Our focus was on the neighbouring cantons of Neuchâtel (180,000 inhabitants) and Jura (70,000 inhabitants). They were chosen because their potential amalgamation has been discussed and because they already collaborate in policy areas including education, health, data protection, public safety, and river management. The questionnaire was sent to all members of the two cantonal parliaments. They have annual debates about their canton's budget and are thus aware of the degree to which exiting intercantonal joint ventures limit their budgetary room to manoeuvre. 
We limit ourselves to presenting here the two questions related specifically to the resistance threshold. The first was: "Above which share of the canton's expenditure that would escape budgetary discussion at the cantonal level could you contemplate an amalgamation?". Respondents were asked to tick one of ten boxes, graduated from 0 per cent to 100 per cent; 100 per cent represented a situation in which all government activities would be shared and 0 per cent would be situation of no cooperation at all. The second question was: "Above which share of the canton's expenditure that would escape budgetary discussion at the cantonal level would you consider an amalgamation of cantons to be indispensable?" Again, respondents were asked to tick one of ten boxes, graduated from 0 per cent to 100 per cent.

The survey was conducted during the second quarter of 2015.47.3 per cent of the 91 MPs from the Jura and 39.1 per cent of the 151 MPs from Neuchâtel replied, generating an overall response rate of 42.2 per cent, in other words, 102 of the 252 MPs. The item response rate was lower as given questions were not always answered.

\section{Elicited Resistance Thresholds}

Figure 10.1 is based on the responses from the 78 MPs who answered both 'threshold' questions. The vertical axis shows the cumulative frequency; above 50 per cent $(0.5)$ means a majority of the responding MPs is reached (dotted line). From a 50 per cent uncontrolled expenditure share, the majority of the responding MPs could contemplate cantonal amalgamation and this share needs to reach at least 60 per cent of the budget before the majority of the respondents stated that an amalgamation is indispensable.

The situation is almost the same when analysing the cantons separately. From a 50 per cent share of expenditure that would be uncontrolled, the majority of the $30 \mathrm{MPs}$ from the Jura who answered both 'threshold' questions, and 48 from Neuchâtel, could contemplate amalgamating the cantons. The share of the budget needs to reach 60 per cent for Jura and 70 per cent for Neuchâtel MPs before most respondents state that amalgamation is indispensable. This finding suggests that a decision to amalgamate is achievable when the identified budget share is perceived as no longer under parliamentary control.

However, the current share of expenditures relative to intercantonal collaboration in Neuchâtel is actually about 5 per cent. At such a low level, 


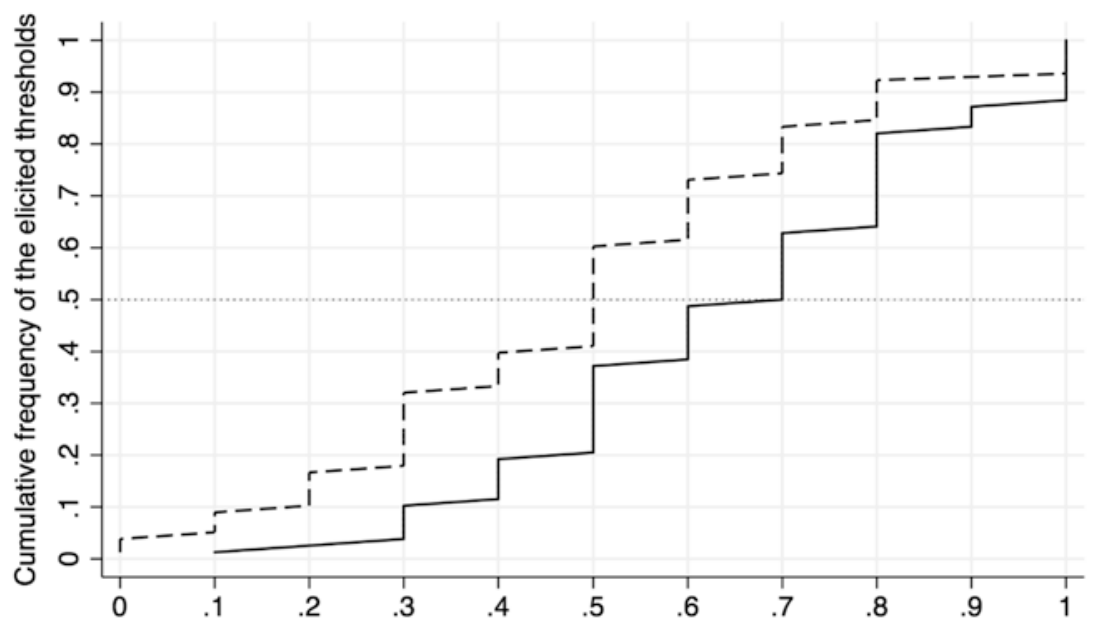

Share of the canton's expenditure escaping the budgetary discussion

Fig. 10.1 Cumulative frequency of the elicited thresholds for a conceivable and indispensable amalgamation $(\mathrm{N}=78)$

it is hardly surprising that a movement towards an amalgamation has remained unsuccessful.

\section{Modelling the Resistance Threshold}

An econometric model was estimated in order to identify which variables have an impact on the elicited thresholds. The indispensable amalgamation threshold was used as the dependent variable. Given that the threshold is a percentage (a limited dependent variable constrained between values of 0 and 1 ), a two-limit Tobit regression model was used to allow for both upper and lower censoring. After dropping all missing values for the different variables, 51 observations remained. Various checks were conducted to ensure our results were robust with respect to alternate specifications and that the model has good explanatory power. Table 10.1 presents the results for the statistically significant variables only. ${ }^{4}$ 
Table 10.1 Tobit Regression Model explaining the threshold for an indispensable amalgamation (dependent variable)

\begin{tabular}{lcc}
\hline Explanatory variables (significant variables only) & Coefficient & $\begin{array}{c}\text { Robust Std. } \\
\text { error }\end{array}$ \\
\hline $\begin{array}{l}\text { 1. Cooperation reduces the control over the budget } \\
(-2=\text { 'fully disagree'; }+2=\text { 'fully agree') }\end{array}$ & $-0.082^{* * *}$ & 0.026 \\
$\begin{array}{l}\text { 2. Readiness to consider amalgamation (yes }=1,0 \\
\text { otherwise) }\end{array}$ & $-0.150^{*}$ & 0.077 \\
$\begin{array}{l}\text { 3. Cooperation is generally and a priori justified } \\
\quad-2=\text { 'not at all'; }+2=\text { 'yes, absolutely') }\end{array}$ & $-0.122^{* * *}$ & 0.036 \\
$\begin{array}{l}\text { 4. Number of parliamentary debates on cooperation } \\
\text { projects between cantons }(0 \text { to } 10)\end{array}$ & $0.062^{* * *}$ & 0.019 \\
$\begin{array}{l}\text { 5. Number of years in canton (numerical) } \\
\text { 6. Minority party (1 when }<10 \% \text { of seats in } \\
\text { parliament; 0 otherwise })\end{array}$ & $-0.007^{* * *}$ & 0.001 \\
$\quad$ Constant & $0.158^{*}$ & 0.973 \\
$\begin{array}{l}\text { Observations } \\
\text { R-squared (OLS robust model) }\end{array}$ & $0.973^{* * *}$ & 0.151 \\
\hline
\end{tabular}

${ }^{* * *} p<0.01,{ }^{*} p<0.10$

1. In line with our hypothesis, the elicited threshold is significantly (at a 0.01 level) higher when the respondents agree that increasing intercantonal cooperation reduces the control over the budget. This suggests that the threshold is lower for MPs who perceive horizontal cooperation as inducing a democratic deficit.

2. Respondents who indicate beforehand that they would be ready to consider amalgamation seem to give a lower threshold than those who say they're not prepared in principle to merge. This reflects the principle-based reluctance - or conversely - the readiness of MPs to consider amalgamation, independent of a specific level of threat to budget control. The variable is only significant at a 10 per cent level. It nevertheless suggests a reluctance, possibly caused by attachment to the canton and social identification. This is in agreement with existing literature (e.g. Zimmerbauer and Paasi 2013) and the putative explanations given when a merger proposal is rejected in a referendum.

3. Additionally, significantly lower amalgamation thresholds (at the 0.01 level) are elicited from MPs who regard intercantonal cooperation generally and a priori justified. It suggests that MPs who find 
cooperation justified per se foster amalgamation through a decrease in their threshold.

4. However, MPs who have actually been confronted with intercantonal cooperation during parliamentary debates are more critical. Indeed, the higher the number of parliamentary debates dealing with cooperation projects between the two cantons the respondent has participated in, the higher the elicited threshold ( 0.01 significance level). This may indicate that an asymmetry of information exists between freshly elected MPs and their more experienced colleagues.

5. The threshold decreases slightly but significantly with the number of years the respondent has spent in the canton. This result suggests that newcomers to a canton are slightly less willing to accept an amalgamation. This may be because they need to construct a local identity for themselves. This is in line with previous findings.

6. Interestingly, belonging to a minority party seems to increase the resistance threshold, although at a level of significance of only 10 per cent. Consistently, MPs from a minority party should express a stronger fear of amalgamation because they incur a higher risk of losing political power, that is, being lost in the crowd of a large population.

\section{Conclusion and OutLOOK}

The likelihood that an amalgamation with other jurisdictions would be accepted increases when share of the budget earmarked to finance joint ventures increases. Our study shows that when the share of the canton's expenditure escaping the budgetary discussion exceeds 60 per cent, a majority of the respondents state they would consider amalgamation indispensable. The estimated regression model further supports the hypothesis that a perceived democratic deficit triggered by extensive joint ventures lowers the threshold. Although at a level of significance of only 10 per cent, an intrinsic reluctance to consider amalgamation increases the threshold. This suggests that factors like cantonal attachment and social identification has an impact on an MP's decision to accept a merger of cantons.

From a policy outlook, this chapter provides an explanation-and a prediction-for the high rejection rate of proposed amalgamations between cantons. In countries where merger decisions are in the hands of subnational parliaments, our study suggests a point at which policy-makers 
should cease cooperation arrangements and argue for merger. Indeed, taking the mechanisms into account is of critical relevance for the future democratic legitimation of the decisions reached. In the Swiss cantons, the actual share of the budget earmarked to finance joint ventures stands at considerable distance from reaching the thresholds stated by majority of the MPs surveyed. Still even a level as low as 5 per cent is enough for some MPs to contemplate amalgamating cantons-though this is a very small minority.

Further, our results may explain why in countries where amalgamation between regions or municipalities have been enforced by the upper-tier, this decision had to be reversed, leading to a partition. Perhaps the resistance threshold necessary to make an amalgamation acceptable had not been reached beforehand and will not be reached even in a distant future. Therefore the upper-tier should refrain to force the amalgamation of subnational jurisdictions unless strictly indispensable.

The key contribution is to identify a strong reluctance among certain cantonal MPs toward the idea of merging neighbouring cantons. Evidently, when cooperation and partnership arrangements between cantons reach a relatively high level, some MPs seem more willing to contemplate merger, perhaps in part due to perceived losses in the control over budgetary decisions. The results may help understanding the implications of any amalgamation plan, including at the European level. Conversely, they also contribute to anticipating the centrifugal forces that may develop in the future of federalism when the share of earmarked resources in the budget increases for joint ventures initiatives.

Nevertheless, the study is limited by its inherent hypothetical nature and its limited number of observations. Further, although our framework can be generalised to any decision-maker of a jurisdiction (i.e. citizens or MPs), our empirical estimation is made with MPs. These latter might not have the same resistance threshold as citizens. However, it is not clear how their views differ regarding an amalgamation. It is worth noting that their position as MPs might be challenged after an amalgamation and this additional fear possibly inflates the identified resistance threshold.

\section{Notes}

1. The International Public Sector Accounting Standards (IPSAS 8) define a joint venture as a binding arrangement whereby two or more parties (e.g. states) are committed to undertake an activity that is subject to joint control (e.g. provision of a given public service). 
2. Each time the debates revolved around putative advantages and disadvantages of amalgamations. Among the advantages: efficiency gains in providing public services, reducing tax pressures and externalities due to better coordination of land-use planning, and greater prominence with respect to economic development. Among the disadvantages: fear of dominance by the larger party to the amalgamation, loss of political self-determination, loss of identification with the community, instability of institutions and borders, and weaker representation in the upper chamber of the national parliament.

3. For the details, see Soguel and Jaquerod (2018).

4. Detailed results are presented in Soguel and Jaquerod (2018). Insignificant variables are, for instance, the evolution of the budget share dedicated to intercantonal cooperation, the readiness of MPs to consider an amalgamation independent of a specific level of threatened loss of budget control, the respondent's gender, and whether the responding MP belongs to a majority party.

\section{REFERENCES}

Aulich, C. (1999). From convergence to divergence: Reforming Australian local government. Australian Journal of Public Administration, 58(3), 12-23.

Blåka, S. (2017). Does cooperation affect service delivery costs? Evidence from fire services in Norway. Public Administration, 95, 1092-1106.

Calciolari, S., Cristofoli, D., \& Macciò, L. (2013). Explaining the reactions of Swiss municipalities to the 'amalgamation wave': At the crossroad of institutional, economic and political pressures. Public Management Review, $15(4), 563-583$.

Court of Auditors/Cour des comptes du Canton of Vaud. (2016). Audit sur l'organisation, le financement et le contrôle démocratique des associations de communes vaudoises. Rapport $\mathrm{n}^{\circ}$ 38. Lausanne. https://www.vd.ch/fileadmin/ user_upload/organisation/cour_comptes/1_Rapports_d_audit/38_Rapport. pdf. Accessed 6 Jan 2020.

Dafflon, B. (2000). Fusions de communes: Eléments d'étude pour une dimension de référence. Revue d'Economie Régionale et Urbaine, 5, 841-860.

Dafflon, B. (2013). Voluntary amalgamation of local governments: The Swiss debate in the European context. In S. Lago-Peñas \& J. Martinez-Vasquez (Eds.), The challenge of local government size: Theoretical perspectives, international experience and policy reform (pp. 189-220). Cheltenham: Edward Elgar.

Dearlove, J. (1979). The reorganisation of British local government: Old orthodoxies and a political perspective. Cambridge: Cambridge University Press Archive. 
Hanes, N., Wikström, M., \& Wångmar, E. (2012). Municipal preferences for state-imposed amalgamations: An empirical study based on the Swedish municipal reform of 1952. Urban Studies, 49(12), 2733-2750.

Jacobs, A. J. (2004). Federations of municipalities: A practical alternative to local government consolidations in Japan? Governance, 17(2), 1468-1491.

Keating, M. (2013). Rescaling the European state: The making of territory and the rise of the meso. Oxford: Oxford University Press.

Olson, M. (1969). The principle of "fiscal equivalence": The division of responsibilities among different levels of government. American Economic Review, $59(2), 479-487$.

Ruggie, J. G. (1993). Territoriality and beyond: Problematizing modernity in international relations. International Organization, 47(01), 139-174.

Rühli, L., \& Rother, N. (2017). NFA 2 - Towards a revitalisation of Swiss federalism. Zürich: Avenir Suisse. https://cdn.avenir-suisse.ch/production/ uploads /2012/01/NFA-2\%E2\%80\%93Towards-a-Revitalisation-of-SwissFederalism-g.pdf. Accessed 6 Jan 2020.

Rumley, P. A. (2010). La Suisse demain: De nouveaux territoires romands, un nouveau canton du Jura: utopie ou réalité? Pontarlier: Editions du Belvédère.

Schöni, A. (2005). Le contrôle parlementaire des conventions intercantonales. Working paper 4. University of Lausanne: IDHEAP.

Sciarini, P., \& Bochsler, D. (2006). Réforme du fédéralisme suisse: Contribution, promesses et limites de la collaboration intercantonale. In J.-L. Chappelet (Ed.), Contributions à l'action publique/Beiträge zum öffentlichen Handeln (pp. 267-285). Lausanne/Bern: Presses polytechniques et universitaires romandes/Haupt.

Soguel, N., \& Jaquerod, M. (2018). Resistance threshold to jurisdictions' amalgamation: a survey of MP's attitude toward budget control and social identification. Working Paper 8. University of Lausanne: IDHEAP.

Soguel, N., \& Silberstein, J. (2015). Welfare loss with municipal amalgamations and the willingness-to-pay for the municipality name. Local Government Studies, 41(6), 977-996.

Tajfel, H., \& Turner, J. C. (1979). An integrative theory of intergroup conflict. In W. G. Austin \& S. Worchel (Eds.), The social psychology of intergroup relations (pp. 33-47). Monterey: Brooks/Cole Publishing Company.

Vetter, A., \& Kersting, N. (2003). Reforming local government: Heading for efficiency and democracy. In A. Vetter \& N. Kersting (Eds.), Reforming local government in Europe (pp. 333-349). Wiesbaden: VS Verlag für Sozialwissenschaften. 
von Hagen, J. (2002). Fiscal federalism and political decision structures. In R. Blindenbacher \& A. Koller (Eds.), Federalism in a changing world. Learning from each other (pp. 373-394). Montreal: McGill-Queen's University Press.

Wollmann, H. (2010). Comparing two logics of interlocal cooperation: The cases of France and Germany. Urban Affairs Review, 46(2), 263-292.

Zimmerbauer, K., \& Paasi, A. (2013). When old and new regionalism collide: Deinstitutionalization of regions and resistance identity in municipality amalgamations. Journal of Rural Studies, 30, 31-40. 